依 頼 論 文

特集：顎関節症治療法の変遷

口腔外科領域における顎関節症の治療法

柴田 考典

\title{
Therapeutic Modalities for Temporomandibular Joint Arthrosis in the Speciality of Oral and Maxillofacial Surgery
}

Takanori Shibata, DDS, PhD

\begin{abstract}
抄 録
目的：本稿の目的は，顎関節症における各種治療法のうち口腔外科領域が主として担当する薬物療法，理 学療法, および手術的治療法について治療成績を文献的に検証し, 確証の得られている治療法および治療 法の選択基準を明らかにすることである.

方法：2012 年 4 月 1 日の時点における顎関節症ないし temporomandibular disorders (TMD) の薬物療 法, 理学療法, および手術的治療法についてのランダム化比較試験 (RCT), システマティック・レビュー (SR), コクランライブラリー・レビュー（コクラン・レビュー）およびメタアナリシス（Meta-A）を電 子的に Medline, Cochrane Database of Systematic Reviews，医中誌から検索した．次いで抽出された 論文の採用している RCT を研究デザインの均質性と妥当性により再評価した。

結果 : 薬物療法, 関節洗浄療法, 関節鏡手術についてコクラン・レビューがあり, RCT, SR, Meta-A と もに薬物療法が最も多く, 手術的治療法がそれに次いでいた。

結論 : 顎関節症に対する効果が認められたのは自己開口訓練, 非ステロイド系鎮痛抗炎症薬の内服および 針治療であった。今後，顎関節症における均質な RCT の蓄積が望まれる。
\end{abstract}

和文キーワード

顎関節症, 薬物療法, 理学療法, 手術的治療法, 治療成績

\section{I . 緒 言}

顎関節症は，第 10 回日本口腔科学会総会（名古屋, 1956）において上野 正らによる一般演題「頼関節症 の研究（第 1 報）臨床的所見」の発表に始まる ${ }^{1,2)}$. 命 名初期は，もつぱら顎関節症における臨床像および成因 に関する報告 ${ }^{3,4)}$ に始まり, 治療法に関しては病態が不 明なため, 対症療法, すなわち薬物療法, 顎間固定など の運動制限療法，咬合調整などが行われていた ${ }^{5)}$.

その後, 半世紀以上の時日経過により, CT, MRI な どの画像診断技術の革新により顎関節腔内を中心とする 軟・硬組織における病態の解明が格段に進しだ。一方, 治療法に関しては，本邦では関節円板を保存する各種低
侵襲手術的法が導入さ机徐々に普及してきたものの明ら かな進展が見られたとは言い難い.

この間の顎関節症に関する治療法の転換点は，2 回 あったと考えられる。すなわち，1回目は顎関節症の病 態として顎関節円板の転位が明らかにされた時点 ${ }^{6,7)}$ で あり，2 回目は転位した関節円板による各種病態の自然 経過が自己限定的であり ${ }^{8)}$, 治療による転位円板の制御 が難しいばかりでなく，関節円板の転位と臨床症状，特 に痛みと必ずしも関連しないことが判明した時点 ${ }^{9,10)}$ と考えられるであろう。

本稿では，本邦において顎関節症に顎関節円板前方転 位の概念が導入された ${ }^{11)}$ 以降における薬物療法, 理学 療法, および手術的治療 (パンピング・マニピュレーシ ヨンを含めて）について，それらの治療成績とそれらを 
踏まえた治療法の適応の変遷について概説する.

なお，本稿で用いる顎関節症の概念 ${ }^{12)}$ および診断基 準 ${ }^{13)}$ は，一般社団法人日本顎関節学会が発表している 基準に従うことをお許しいただきたい，また，欧米では temporomandibular disorders (TMD) ないし temporomandibular joint disorders（TMJD）という疾患 概念を採用しており，それらの診断基準として Research Diagnostic Criteria for TMD (RDC/TMD) ${ }^{14)}$ が普及している，両者の相違はあるが，本邦の業績だけ では裏付けのある治療法の評価は不可能であり, 相違を 理解したうえで欧米の業績も広く採用した。

\section{II．顎関節症に対する治療法（表 1）}

非手術的治療法と手術的治療法とに大別される，前者 は生活改善・セルフケアー, スプリント療法, 咬合治療, 認知行動および心身医学療法, 精神神経科との連携（向 精神薬などの薬物療法), 薬物療法 (表 2), 理学的療法 （表 3）などからなる。一方，手術的治療は，関節腔洗 浄療法, パンピング・マニピュレーション, 関節鏡視下 手術，および関節開放手術からなる.

ここでは, 薬物療法 (NSAIDs, 中枢性筋弛緩薬など の内服薬，ステロイド薬やヒアルロン酸などの関節腔注 入薬など), 理学的療法, 関節腔洗浄療法, パンピング • マニピュレーション，関節鏡視下手術，および関節開放 手術について, それらの治療成績および適応の変遷を含 めて述べる.

\section{1. 治療対象}

まず，顎関節症と診断された患者 ${ }^{13)}$ が必ずしもすべ て治療対象になるわけではなく, 何らかの日常生活上の 障害が認められることが必要条件となる。

\section{2. 治療目標}

治療目標は, 臨床的には短期的には顎関節部および咀 嚼筋部の痛みの緩解と機能障害の改善により, 各種の生 活障害の回復を図ることであり，さらに長期的には再発 を防止することである。

しかし，治療により到達する病態は，顎関節症の病態 により異なる。すすなわち, 咀嚼筋障害, 関節包・勒帯障 害，および関節円板障害の軽度のものについては関節円 板転位のない完治 (40 mm 以上の開口距離と日常生活 障害がない) を目標とすることができる場合が多い.

一方, 大部分の関節円板障害, 変形性顎関節症では, 器質的変化の復旧は望めず, $35 \mathrm{~mm}$ 以上の開口距離, 日常生活障害が軽度残存しても満足せざるをえない場合
表 1 Therapeutic modalities 顎関節症の治療法

I. 非手術的治療 (non-surgical modalities)

1. 生活改善, セルフケアー, 栄養補助食品 (lifestyle adaptation, self-managing, supplement)

2. 薬物療法 (pharmacologic therapies)

3. 理学療法 (physical medicine modalities)

4. スプリント療法 (oral appliances)

5. 咬合治療 (management of dental occlusion)

6. 認知行動および心身医学療法 (cognitive-behavioral and psychological treatment)

II. 手術的治療 (surgical modalities)

1. 関節腔洗浄療法 (arthrocentesis)

2. パンピング・マニピュレーション (pumping manipulation)

3. 関節鏡視下手術（arthroscopic surgery）

4. 関節開放手術 (open surgery)

がある．後者の場合には長期の管理が必要となる.

\section{3. 治療法の評価}

顎関節症における治療法の評価において，バイアスの 混入する可能性が最も低い研究デザインが無作為化比較 対照試験(ランダム化比較試験, randomized controlled trial, 以下 RCT と略す) であり ${ }^{15)}$ ，均質性の 高い複数の RCT によるシステマティック・レビュー (以下, SR と略す) ${ }^{16)}$ およびメ夕分析, コクランデータ ベース・システマティック・レビュー (Cochrane Database of Systematic Reviews，以下，コクラン・レビ ューと略す）を基に，それらがない治療法については RCT を検索し用いた，なお，顎関節症と TMD では疾 患概念が異なるので，TMDの RCT において顎関節症 に含まれない疾患（リウマチ性顎関節炎，滑膜軟骨腫症 など）を対象としているものは除外した.

\section{4. 治療法の選択基準}

顎関節症に対する各種治療法を一括して評価した SR およびコクラン・レビューはなかった。

一方, TMD の複数の治療法について 23 編の SR と 7 編のメ夕分析とを評価したところ, 30 編の研究デザ インに均質性がないため明確な結論には至らないとした うえで, TMD の痛み軽減についてはスプリント療法, 針治療, 行動療法, 姿勢訓練, ある種の薬物療法が効果 を示す可能性があるが, 電気的理学療法と手術は根拠が 不十分であり，咬合調整は効果がないと報告してい 
$3^{17)}$.

痛みを伴う非復位性円板転位群，重大な精神医学的症 状を伴わない関節痛群，および重大な精神医学的症状を 伴う群の 3 群にわけ，それぞれの群について歯科医師 のケアーのみの単純治療と 2 種類以上の治療法を組み 合わせる複合治療との効果を比較したところ, 前 2 群 では単純治療と複合治療との間で効果に差がなかったと 述べている ${ }^{18)}$.

顎関節における変形性関節症に対する各種治療法を一 括して評価したコクラン・レビュー ${ }^{19)}$ があるが，わず か 3 編の RCT ${ }^{20-22)}$ が選択されたに止まり，メ夕分析に いたっていない. しかも，それらはそれぞれ関節腔注入 薬のベタメサゾン (ステロイド薬) とヒアルロン酸 ${ }^{20)}$, スプリント療法とジクロフェナク (NSAID) ${ }^{21}$ ， イブプ ロフェン (NSAID) とグルコサミン (栄養補助食品) ${ }^{22)}$ との痛みに対する効果がほぼ同等であることを示してい るのみである.

\section{III. 薬物療法（表 2)}

TMD の痛みに対する各種薬物療法を一括して評価し たコクラン・レビューがある ${ }^{23)}$ が, 11 編の RCT が選 択されたに止まり，メ夕分析に至っていない. 大部分は 対象例が少なく, TMD の痛みに対する効果を判断する ための根拠を提供できていない. 11 編のうち, プラセ ボと NSAIDs に属するピロキシカム ${ }^{24)}$ ，ジクロフェナ クナトリウム ${ }^{25)}$, ナプロキセン ${ }^{26)}$, シクロオキシゲナー ゼ (COX) 2 阻害薬 ${ }^{26)}$ ，メチルサリチレート・クリー ${ }^{2}{ }^{27)}$ ，中枢性筋弛緩薬に属するシクロベンザプリン ${ }^{28)}$ の RCT が本稿に関連した薬物である。これらのうちナ プロキセン ${ }^{26)}$ のみがプラセボより有意な鎮痛効果を示 したが，中等度以上の疼痛が最低 3 力月間持続してい る患者が被験者として至適条件にも関わらず，疼痛持続 期間が 6 週間と短くプロトコールを満たしていない点 から, 評価の対象から除外される。

小括：顎関節症に対する薬物療法の系統的な適応基準 は明らかとなっていない.

\section{1. 内服薬}

1) 非ステロイド系消炎鎮痛薬

本邦において，比較試験なしに顎関節症の適応を得ら れた非ステロイド系消炎鎮痛薬（以下，NSAIDs と略 す)はアンフェナック・ナトリウム(フェナゾックス ${ }^{\circledR 29)}$ が最後であり, その後の 1998 年の新 Good Clinical Practice (GCP) の施行以降, 顎関節症における顎運 動時の顎関節痛に対してプラセボとピラノ酢酸系
表 2 Pharmacological therapies 顎関節症の薬物療法

1. 内服薬 (oral medicine)

1）非ステロイド系消炎鎮痛薬 (nonsteroidal anti-inflammatory drugs; NSAIDs)

2）中枢性筋弛緩薬 (muscle relaxants)

3) 麻薬系薬物 (opioids)

4) ベンゾジアゼピン系薬物（benzodiazepinees）

5) 抗うつ薬 (antidepressants)

2. 関節腔注入薬（intracapsular injected agent）

1）副腎皮質ステロイド薬（corticosteroids）

2）ヒアルロン酸（hyaluronic acid）

NSAIDs であるエトドラグの RCT が実施されたが，効 果に有意差がみられなかった。その後，RCT を経て顎 関節症の薬事承認を獲得した薬物は皆無である. 日本顎 関節学会は的確な RCT を実施できる体制を整備するた めに顎関節症の診断精度の向上にむけて, 顎関節症の診 断基準や症型分類に力を注いできた。なお，この観点か らも成果にそしいと言わざるを得ない ${ }^{30}$.

一方，社会保険診療報酬支払基金が設置している「審 査情報提供検討委員会」において，医薬品の適応外使用 に係わる保険診療上の取り扱いについての検討で，顎関 節症の顎関節痛に対し，ロキソブロフェンナトリウム水 和物 (ロキソニン ${ }^{\circledR 31}$ ， ジクロフェナク (ボルタレン ${ }^{\circledR 32}$ およびナブロキセン（ナイキサン ${ }^{\circledR 3}{ }^{33}$ が承認された（保 医発 0928 第 1 号 : 2011 1.9.28).

日本歯科薬物療法学会では顎関節症の関節痛に対する 消炎鎮痛薬診療ガイドライン (2011 年 9 月 28 日修正 版） ${ }^{34)}$ を公開しており，推奨度は弱いものの顎関節症の 関節痛を有する患者に NSAIDs は有効としている。た だし, 投与に先立ち最新の添付文書情報を熟知して使用 すること，投与方法は時間投与が原則であること， 7 日 分以上の連続投与は避け, 副作用に注意して効果判定を 行うことなどのコメントが添えられている.

小括：顎関節症の関節痛を有する患者に消炎鎮痛薬は 有効である（推奨の程度：弱いが推奨する）.

2) 中枢性筋弛緩薬

前述したシクロベンザプリン ${ }^{28)}$ は，効果が確認され ていないとともに，本邦で市販されていない，一方，本 邦ではトリペリゾン塩酸塩に対する RCT, および咀嚼 筋等の筋緊張ないし筋痛を伴う顎関節症に対してプラセ ボと塩酸ランペリゾンの RCT を実施したが，有意差が みられなかった ${ }^{35,36)}$.

小括：RCT により顎関節症に対する効果が立証され 
た中枢性筋弛緩薬はない.

\section{2. 関節腔注入薬}

1）副腎皮質ステロイド薬

顎関節症および TMD に対する副腎皮質ステロイド 薬の効果に関するメ夕分析はなく, RCT は本邦の報 告 ${ }^{37)}$ のみである。すなわち, 非手術的治療にて関節痛 の改善を認めなかった片側性関節痛を有する顎関節症患 者 49 例を関節腔洗浄療法単独と関節洗浄後にステロイ ド剤注入とでRCT を行ったところ，関節痛と開口域の 改善に差がなかったと報告している。

一方, 関節洗浄療法後の疼痛とこわばりに対してデキ サメサゾン関節腔内注入とプラセボ (生理食塩液) とで

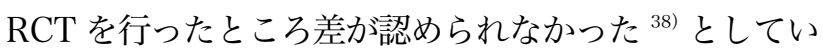
る.

小括：顎関節症に対するステロイド薬を単独ないし関 節洗浄後の関節腔内注入効果は認められていない.

2) ヒアルロン酸ナトリウム

顎関節疾患に対するヒアルロン酸注入に対するコクラ ン・レビュー ${ }^{39)}$ および $\mathrm{SR}^{40)}$ がある. 前者では研究デ ザインが等質な RCT が選択されておらず，メ夕分析に いたっていない. 後者では抽出された 19 編のうち 7 編が他の炎症性退行性関節疾患であり評価対象外とさ れ，残りの関節円板障害への効果をみた論文 12 編で は，ほとんどが RCT の要件を満たしておらず評価すべ き結果を示していない.

一方，本邦では関節包・勒帯障害 (II 型), 関節円板 障害 (IIIa, b 型) および変形性関節症 (IV 型) と診断 され，かつ顎関節部に限局する痛みを有する顎関節症に 対してプラセボ $(0.01 \%$ ヒアルロン酸ナトリウム) と $1 \%$ ヒアルロン酸ナトリウムとの RCT を実施したが, 有意差がみられなかった ${ }^{41,42)}$.

小括 : 顎関節症のヒアルロン酸注入療法についてもそ の効果を積極的に支持する報告はない.

\section{IV. 理学療法 (表 3)}

顎関節症の理学療法には，顎運動療法，ストレッチ， マッサージ, マニピュレーション, EMG バイオフィー ドバック療法，超音波・温熱療法低出力レーザー照射療 法 TENS, 低周波電流通電療法, 針治療など多岐にわ たる. TMD に対する各種理学療法を一括して評価した $\mathrm{SR}$ が 2 編 $\left.{ }^{43}, 44\right)$ があるが，低質な研究デザインばかり でなく, RCT の採用ないし除外基準, 成績の評価と信 頼性に疑問があり, RCT の均質性が担保できないので 評価できない. なお，本邦では歯科医師が自ら理学療法
表 3 Physical medicine modalities 顎関節症の理学療法

1. 顎運動療法, ストレッチ (jaw exercise/stretching)

2. マッサージ, マニピュレーション (massage/jaw manipulation)

3. 筋電図バイオフィードバック療法 (EMG biofeedback therapy)

4. 超音波・温熱療法（ultrasound/thermal therapies）

5. 低出力レーザー照射療法 (low-level laser therapy)

6. TENS, 低周波電流通電療法 (electronic stimulation)

7. 針治療 (acupuncture)

の指導を行うのが一般的であるのに比べ，米国では歯科 医師が関与せず理学療法士が害施する場合がほとんどで ある.さらに，欧米では 1997 年 11 月に開催された針 治療に関する NIH 声明 ${ }^{45)}$ を以降，多額の grant が費 やされきわめて多くの業績が出されており，TMDに関 しても他の治療法に比して格段に報告が多い.

小括：顎関節症における理学療法の系統的な適応基準 は明らかとなっていない.

\section{1. 顎運動療法/ストレッチ}

㖽運動療法のうち自己開口訓練については, 一般社団 法人日本顎関節学会初期治療ガイドライン作成委員会が 「開口障害を主訴とする，関節円板転位に起因すると考 えられる顎関節症患者（III 型 b) に対する患者自身が 徒手的に行う開口訓練は有効か」という臨床上の疑問に 対して, 3 編の RCT ${ }^{46-48)}$ を抽出し GRADE システム ${ }^{49)}$ 用いて解析し開口障害を主訴とする関節円板転位に起因 すると考えられる顎関節症患者 (III 型 b) において, 関節円板の位置など病態の説明を十分に行ったうえで, 患者本人が徒手的に行う開口訓練（鎮痛剤の併用は可） を行うことを提案する (GRADE 2B : 弱い推奨/“中” の質のエビデンス), という一般歯科医師向けの診療ガ イドラインを発表している ${ }^{50)}$. なお, このガイドライ ンは，注意事項として以下の項目を挙げている.

（1）開口訓練については，一日数回，患者が本人の指 を用いて著しい強制でないストレッチ的な開口を行うも のとする．また，開口訓練によって，日常生活上で顎関 節部の疼痛が増大する場合は中止するものとするが，開 口訓練時に若干の疼痛が生じることを事前に説明するこ ととする.

（2）病悩期間については，初診数日前に生じた急性開 口障害などで疼痛が大きい場合は専門医に紹介，または 2 週間ほど治療開始を遅らせるなどの慎重な対応が必要 
である。

（3）病態説明については，図を使って十分に説明する こと.

（4）コンプライアンスについては，訓練の意義や，リ ハビリテーションの一環としての重要性を説明して，患 者の開口訓練に対するモチベーションを高める必要が指 摘された。

（5）今回採用した論文の研究デザインは，あくまでも 鎮痛剤の服用を伴う開口訓練であったが，鎮痛剤の併用 は必須としないこととした。

2. マッサージ, マニピュレーション

マニピュレーションについては，2 編の $\mathrm{RCT}^{51,52)}$ が あり，1 編 ${ }^{51)}$ は円板障害に対する初期治療として，又 プリント療法やマニピュレーションを主体とした理学療 法と，薬物療法や軟性食の指導とを無治療経過観察例と 比較する RCT を行ったところ，3 群間で差がなかっ た. 他の 1 編 ${ }^{52)}$ は $35 \mathrm{~mm}$ 以下の開口制限を有する 34 名の顎関節症患者を自律運動療法単独群と, 自律運動療 法と manipulation technique 療法との併用群とにブ ロックランダム化比較，2 群間で疼痛に差はなかった が，J-MAT 併用群で開口量の有意な増加を認めたと報 告しているが，2編の結果が異なること，両者はとも単 独治療でないこと，など研究デザインの均質性に問題が あり結論に至らない。

\section{3. 筋電図バイオフィードバック療法}

EMG バイオフィードバック療法単独は, メ夕分析の 結果 TMD 治療の効果は認められていない ${ }^{53,54)}$.

\section{4. 超音波・温熱療法, TENS，低周波電流通電療法}

TMD に対する超音波・温熱療法，TENS，低周波電 流通電療法の RCT は全くなく，評価できない.

\section{5. 低出力レーザー照射療法}

低出力レーザー照射療法については 1 編の $\mathrm{SR}^{55)}$ が ありメ夕分析の結果，TMD 治療における効果は認めら れていない.

\section{6. 針治療}

4 編の SR が抽出され，それぞれが 14 編の RCT か らの SR の結果，中等度のエビデンスをもつて TMD 症 状の改善効果 ${ }^{56)} ， 4$ 編の RCT のメ夕分析の結果，筋原 性の TMD 短期間の除痛効果 ${ }^{57)}$ ，3 編の RCT から治療 効果 ${ }^{58)}$ ， 7 編の RCT からの SR とメ夕分析の結果，顎 関節および咀嚼筋の痛みに関する効果は限定的あるいは
薄弱 ${ }^{59)}$ と結論づけられている。このように解析結果が ばらつくのは，選択される RCT の均質性，対象数など が不十分であることが考えられる。

小括：顎関節症の理学療法では，患者自身が行う開口 訓練および針治療の効果が認められた。

\section{V. 手術的治療}

手術的治療法は関節腔洗浄療法，パンピング・マニピ ユレーション，関節鏡視下手術，関節開放手術に大別さ れる，このうち顎関節鏡の開発および関節鏡の関節腔へ の挿入のための関節穿刺法の確立に対する貢献は大き い. 関節鏡および関節鏡視法は本邦で開発され，世界に 普及した診断・治療法 ${ }^{60)}$ である。 さらに，大西ら ${ }^{61-65)}$ がいち早く関節鏡を小口径化し顎関節の診断および治療 に使用できるように改良し，顎関節の治療における低侵 襲治療法の普及を招いたことは高く評価されている。

関節円板障害に対する関節洗浄療法，関節鏡手術，円 板整位・修復術，円板切除術の効果を検証するととも に，最も効果的な治療法を探索したメ夕分析 ${ }^{66)}$ では, 診断の信頼性，各群の均質性に欠け評価できないと述べ ている. TMJ に詨する効果について手術的治療と非手 術的治療とを比較する SR の方法の質を検証したとこ ろ ${ }^{67)}$ ，前述の論文 ${ }^{66)}$ に含まれた論文は 23 編，患者数 1,463 名，そのうち RCT は 2 編 (8.7\%) で，RCT の 基礎となる患者数は 112 名（8.7\%）であり，その方法 の質基準では $77.5 \pm 12.8 \%$ であり，SR を構成する論 文の質が不十分としている.

いずれにしても，TMD に対する手術的治療法の効果 は明らかにされていない.

小括：顎関節症に対する手術療法に関しては系統的な 適応基準は明らかとなっていない

\section{1、関節腔洗浄療法}

上関節腔に局所麻酔薬を注入し，十分に除痛を図った 後， $21 \mathrm{G}$ 注射針を 2 本（流入針と流出針）刺入し，ま ず， 100-200 ml 以上の生理食塩液ないし乳酸加リン ゲル液を用いて潅流する方法である。本法は Nitzen ${ }^{68-71)}$ らにより治療法として確立された。

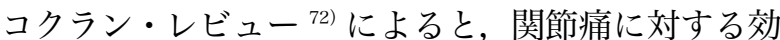
果は関節腔洗浄療法と関節鏡視下手術との間に有意差は なく ${ }^{73,74)}$ ，開口距離の増大に関しては関節鏡視下手術 の方が統計的に有意であった ${ }^{73)}$ と述べている．関節腔 洗浄療法の TMJD に対する効果は，その根拠が脆弱で あり，妥当性に関与する主評価項目および結論の再現性 に問題があり，さらなる上質の RCT が必要と報告して 
いる，選択された 2 編 ${ }^{72,73)}$ は，両者ともは無作為割付 け前向き観察研究であった。 ただし, 関節腔洗浄療法に は，公表されているだけで 8 種の異なる手技が用いら れており ${ }^{75)}$ ，これらの手技が成績にも影響を与える可 能性があり, 今後 SR の評価項目に追加すべきであろ う.

\section{2. パンピング・マニピュレーション}

上関節腔に局所麻酔薬を注入し十分に除痛を図るとと もに，関節腔を十分に拡張させた後，術者は両手で両側 大臼歯部下顎骨を把持し，下顎頭を前下方に誘導するよ うに矯正力を加える.

成功した場合は短期的には開口距離の増加が明らかで あるが成功率も不明であり， RCT はなく短期的効果ば かりでなく長期的効果も立証されていない.

\section{3. 関節鏡視下手術,}

関節鏡視下手術には，鏡視下剥離授動術，鏡視下円板 固定術, 鏡視下関節形成術, 鏡視下円板切除術などがあ り，この順で侵襲の程度が大きくなる。鏡視下剥離授動 術と鏡視下円板固定術は関節包ないし滑膜組織の一部破 綻をきたすが，関節洗浄療法に近似した侵襲程度といえ る. 鏡視下関節形成術と鏡視下円板切除術は関節隆起部 組織や関節円板の切除を行う療法であるから侵襲度は前 2 者より大きいが，関節包ないし滑膜組織の破綻は一部 に限局される。

コクラン・レビュー ${ }^{76)}$ では, 7 編の $\operatorname{RCT}(\mathrm{n}=349)$ が抽出されたが，方法の均質性が担保されていないため SR としても不十分で, メ夕分析は行われていない. な お，抽出された 2 編で 6 力月後の痛みを関節鏡手術群 と非手術療法群とで比べたところ有意差がなかった，2 編で 12 力月後の痛みを関節洗浄療法群と関節鏡手術群 とで比べたところ有意差がなかった。 3 編で 12 力月後 の痛みを関節鏡手術群と関節開放手術群とで比べたとこ ろ関節開放手術群で有意に減少していた. 2 編で 12 力 月後の切歯間最大開口距離を関節洗浄療法群と関節鏡手 術群とで比べたところ関節鏡手術群で有意に増大してい た. ただし，手術的治療は非施術的治療が奏功しなかっ た場合考慮すべきとしている.

小括：関節鏡手術の効果を示す明確な根拠はない.

\section{4. 関節開放手術}

関節開放手術には転位ないし変形した関節円板を保存 する関節円板形成術とそれら関節円板を切除する関節円 板切除術などがある.さらに，関節円板形成術には以下 の術式が含まれる．関節円板を解剖学的にほぼ正常位置
表 4 TMJ open surgery 顎関節開放手術

I. 関節円板に対する術式（meniscus surgery）

1. 関節円板形成術 (meniscoplasty)

1）関節円板整位術（surgical disc repositioning）

2）関節円板修正術（disc recontouring）

3）関節円板修復術（disc repair）

2. 関節円板切除術 (meniscectomy)

1) 円板切除術 (meniscectomy without implant)

2）円板切除後中間挿入物を使用する術式 (meniscectomy with implant)

i）暫間的使用（temporary implant）

ii）永久的使用（permanent implant）

II. 顎関節部硬組織に対する術式（arthroplasty）

1. 関節隆起修正術 (eminence plasty)

2. 下顎頭修正術 (condylar plasty)

に整位する関節円板整位術，そのなかには前方転位し伸 展した円板後部結合組織を楔型に切除・縫縮し整位を図 る円板後部結合組織縫縮術，関節円板の外側縁を下顎頭 外側極に縫合・固定する円板固定術，肥厚した関節円板 形態を修正する関節円板修正術，穿孔部を切除・縫縮す ることにより修復する関節円板修復術とが含まれる。

関節円板切除術は，円板切除術単独と円板切除後に中 間挿入物を使用する術式とに分けられ，後者はさらに中 間挿入物を暫間的に使用する術式とそれらを永久的に使 用す術式とに細分される。

また，関節開放手術では下顎窩，関節隆起および下顎 頭の硬組織変形を削除・修正する下顎窩修正術，関節隆 起修正術および下顎頭修正術があり，適宜併用される (表 4). なお, 皮膚切開の種類には耳後切開法, 耳内切 開法, 耳前切開法があり, 耳前切開法が繁用されている.

関節開放手術は外側の関節包ないし滑膜組織に大きな 侵襲を与え，血液・滑膜関門を破壊するため，適切な術 後療法を実施しなければ関節癒着きたすおそれがあるた め，軟食摂取を中心とする生活指導，顎運動訓練を中心 とする理学的療法，薬物療法，スプリント療法を少なく とも3〜4 カ月間は継続する必要がある.

小括：関節開放手術に関する SR およびRCT はな く, 効果を裏付ける根拠はない.

\section{VI．結語}

以上より，顎関節症の諸治療法において，根拠のある 体系的な選択基準を示すことができないので，まず非手 
術的治療法を第一選択とする，すなわち，患者に顎関節 症が自己限定的な疾患であることを説明し，症状増悪に 対する不安を取り除き，自己管理法（セルフケアー，生 活改善，自己開口訓練）を指導する。治療が必要であれ ば対症療法（NSAIDs の内服あるいは針治療）を行う。 非手術的治療が奏功しない場合には，CT，MRI などの 画像診断を考慮するとともに再度，精査を行うべきであ ろう。やむをえず手術的治療を選択する場合は関節洗浄 療法をまず試みるできであろう。

今後，顎関節症の治療成果を高めるためには，上質な RCT を蓄積する必要があり，そのためには他の研究と 比較可能な診断基準，成績評価基準，痛みの均質的な評 価法，さらに RCT を核とする SR からのフィードバッ クを行うこと ${ }^{77)}$ など課題は多い。

\section{文献}

1）上野 正, 岡 達, 中村充也. 顎関節症の研究(第 1 報)： 臨床的所見 (抄)。日口科誌 1956; 5:284.

2）上野 正。顎関節疾患に関する研究。口病誌 1976;377383.

3）中村充也, 䫄関節症の臨床的研究. 口病誌 1959;26:9861012

4）岡 達. 顎関節症の研究，成因および臨床像を中心に. 口病誌 1967; 16: 116-123.

5）小野尊睦，古川哲夫，大野腪八郎，山田茂樹，福井正義， 横矢 喬ほか。顎関節症治療の遠隔成績について。 日口 外誌 1971; 17: 137-140.

6) McCarty WL Jr, Farrar WB. Surgery for internal derangement of the temporomandibular joint. J ProsthetDent 1979; 42: 191-196.

7) Farrar WB, McCarty WL Jr. A clinical outline of temporomandibular joint diagnosis and treatment, Alabama; Normandie Publications: 1982, 1-182.

8) Kurita K, Westesson PL, Yuasa H, Toyama M, Machida J, Ogi N. Natural course of untreated symptomatic temporomandibular joint disc displacement without reduction. J Dent Res 1998; 77: 361-365.

9) Koh KJ, List T, Petersson A, Rohlin M. Relationship between clinical and magnetic resonance imaging diagnoses and findings in degenerative and inflammatory temporomandibular joint diseases: a systematic literature review. J Orofac Pain 2009; 23: 123139.

10) Palconet G, Ludlow JB, Tyndall DA, Lim PF. Correlating cone beam CT results with temporomandibular joint pain of osteoarthritic origin. Dentomaxillofac Radiol 2012;41: 126-130.

11）柴田考典．関節円板転位例（顎内障）の考元方とその診 断. 補経臨床別冊咬合診断・治療のために, 東京 : 医歯 薬出版；1984, 247-259.
12）日本顎関節学会学術委員会病名検討委員会. 顎関節疾患 および顎関節症の分類（改訂案）日顎誌 1996; 8: 113116.

13）日本顎関節学会顎関節症診断法検討委員会. 顎関節症診 療に関するガイドライン.東京：日本顎関節学会；2011, $1-32$.

14) Dworkin SF. Research diagnostic criteria for temporomandibular disorders: current status \& future relevance. J Oral Rehabil 2010; 37:734-743.

15) Richardson WS, Wilson MC, Williams JW Jr, Moyer VA, Naylor CD. Users' guides to the medical literature: XXIV. How to use an article on the clinical manifestations of disease. Evidence-Based Medicine Working Group. JAMA 2000; 284: 869-875.

16) Howick J, Chalmers I, Glasziou P, Greenhalgh T, Heneghan C, Liberati A et al. The Oxford 2011 Levels of Evidence. Oxford Centre for Evidence-Based Medicine. 201 l; <http://www.cebm.net/index.aspx? $\mathrm{o}=5653>$ [accessed 20 July, 2012].

17) List T, Axelsson S, Management of TMD: evidence from systematic reviews and meta-analyses. J Oral Rehabil 2010;37:430-451.

18) Turp JC, Jokstad A, Motschall E, Schindler HJ, Windecker-Getaz I, Ettlin DA. Is there a superiority of multimodal as opposed to simple therapy in patients with temporomandibular disorders? A qualitative systematic review of the literature. Clin Oral Implants Res 2007; 18 Suppl 3: 138-150.

19) de Souza RF, Lovato da Silva $\mathrm{CH}$, Nasser $\mathrm{M}$, Fedorowicz Z, Al-Muharraqi M. Interventions for the management of temporomandibular joint osteoarthritis. Cochrane Database Syst Rev 2012; 4: CD 007261.

20) Bjørnland T, Gjaerum AA, Møystad A. Osteoarthritis ofthe temporomandibular joint: an evaluation of the effect sand complications of corticosteroid injection compared with injection with sodium hyaluronate. J Oral Rehabil 2007; 34:583-589.

21) Mejersjö C, Wenneberg B. Diclofenac sodium and occlusalsplint therapy in TMJ osteoarthritis: a randomized controlled trial. J Oral Rehabil 2008; 35: 729738.

22) Thie NM, Prasad NG, Major PW. Evaluation of glucosamine sulfate compared to ibuprofen for the treatment of temporomandibular joint osteoarthritis: a randomized double blind controlled 3 month clinical trial. J Rheumatol 2001;28: 1347-1355.

23) Mujakperuo HR. Watson M. Morrison R. Macfarlane TV. Pharmacological interventions for pain in patients with temporomandibular disorders. Cochrane Database Syst Rev 2010; 10: CD 004715.

24) Roldan OV, Maglione H, Carreira R, Mainieri S. Pi- 
roxicam, diazepam and placebo in the treatment oftemporomandibular joint dysfunction. Double blind study. Rev Asoc Odontol Argent 1990; 78: 8385.

25) Ekberg E, Kopp S, Akerman S. Diclofenac sodium as an alternative treatment of temporomandibular joint pain. Acta Odontol Scand 1996; 54: 154-159.

26) Ta LE,DionneRA. Treatment of painful temporomandibular joints with a cyclooxygenase-2 inhibitor: a randomized placebo-controlled comparison of celecoxib to naproxen. Pain 2004; 11 1: 13-21.

27) Lobo S, Mehta N, Forgione AG, Melis M, Al-Badawi E, Ceneviz C et al. Use of Theraflex-TMJ topical cream for the treatment of temporomandibular joint and muscle pain. Cranio 2004; 22: 137-144.

28) Herman CR, Schiffman EL, Look JO, Rindal DB. The effectiveness of adding pharmacologic treatment with clonazepam or cyclobenzaprine to patient education and self-care for the treatment of jaw pain upon awakening: a randomized clinical trial. J Orofac Pain 2002; 16:64-70.

29）柴田考典, 木住野義信, 鬼谷信美, 米津博文, 高野直久, 佐藤和則ほか. 顎関節症に対する Amfenac Sodium (フェナゾックス ${ }^{\circledR}$ )の臨床評価. 日口外誌 1988; 34: 752767.

30）柴田考典．日本顎関節学会の「顎関節症診療に関するガ イドライン」はどのようにして決められたのか. 日㓵誌 2012;24:3-16.

31） http://www.ssk.or.jp/shinsajoho/teikyojirei/files/jirei $233 \#$ page $=2$

32) http://www.ssk.or.jp/shinsajoho/teikyojirei/files/jirei $234 \#$ page $=2$

33） http://www.ssk.or.jp/shinsajoho/teikyojirei/files/jirei $235 \#$ page $=2$

34）日本歯科薬物療法学会。顎関節症の関節痛に対する消炎 鎮痛薬診療ガイドライン (2011 年 9 月 28 日修正版).

2011; www.jsotp.org. [accessed 20 July, 2012]

35）石橋克禮, 柴田考典, 吉澤信夫, 岡 達, 佐藤公治, 木 野孔司ほか. 顎関節症に対する NK-433（中枢性筋弛緩 剂）の臨床的有用性の検討第 1 報：臨床第 II 相試験. 日顎誌 1995; 7: 110-127.

36）石橋克禮，柴田考典，吉澤信夫，岡 達，木野孔司，天 笠光雄にか. 顎関節症に対する NK-433（中枢性筋弛緩 剂）の臨床的有用性の検討第 2 報 : 臨床第 III 相試験. 日顎誌 1995; 7: 128-146.

37）豊田長隆，浅田洸一，荒井智彦，徳富威彦，志賀貴之, 斉藤 高，石橋克禮。顎関節痛を有する顎関節症に対す る関節腔洗浄療法の治療効果（第 1 報）関節腔洗浄単独 例とステロイド凬併用例との比較検討. 日顎誌 1998; 10: 507-514.

38) Huddleston Slater JJ, Vos LM, Stroy LP, Stegenga B. Randomized trial on the effectiveness of dexametha- sone in TMJ arthrocentesis. J Dent Res 2012; 91: 173178.

39) Shi Z, Guo C, Awad M. Hyaluronate for temporomandibular joint disorders. Cochrane Database Syst Rev 2003; 1: CD 002970.

40) Manfredini D. Piccotti F.Guarda-Nardini L. Hyaluronic acid in the treatment of TMJ disorders: a systematic review of the literature Cranio 2010; 28: 166-176.

41）岡 達, 柴田考典, 峰野泰久, 吉澤信夫, 木野孔司, 天笠光雄ほか。顎関節症に対する SI-6601A（ヒアルロ ン酸ナトリウム関節注入製剂) の臨床的有用性の検討第 1 報：前期臨床第 II 相試験。日䫟誌 1994; 6:482-497.

42）吉澤信夫, 柴田考典, 岡 達, 峰野泰久, 木野孔司, 天笠光雄ほか。顎関節症に対する SI-6601A（ヒアルロ ン酸ナトリウム関節注入製剂) の臨床的有用性の検討第 3 報：臨床第 III 相試験。日顎誌 1994; 6: 498-514.

43) McNeely ML, Armijo Olivo S, Magee DJ. A systematic review of the effectiveness of physical therapy interventions for temporomandibular disorders. Phys Ther 2006; 86: 710-725.

44) Medlicott MS. Harris SR. A systematic review of the effectiveness of exercise, manual therapy, electrotherapy, relaxation training, and biofeedback in the management of temporomandibular disorder. Phys Ther 2006; 86: 955-973.

45) NIH Consensus Conference. Acupuncture. AMA 1998; 280: 1518-1524.

46) Minakuchi H, Kuboki T, Matsuka Y, Maekawa K, Yatani H, Yamashita A randomized controlled evaluation of non-surgical treatments for temporomandibular joint anterior disk displacement without reduction. J Dent Res 200 1; 80: 924-928.

47) Yuasa H, Kurita K. Randomized clinical trial of primary treatment for temporomandibular joint disk displacement without reduction and without osseous changes: a combination of NSAIDs and mouthopening exercise versus no treatment. Oral Surg Oral Med Oral Pathol Oral Radiol Endod 2001; 91: 671675.

48) Haketa T, Kino K, Sugisaki M, Takaoka M, Ohta T. Randomized clinical trial of treatment for TMJ disc displacement. J Dent Res 2010;25.

49）相原守夫，三原華子，村山隆之，相原智之，福田眞作. 診療ガイドラインのための GRADE システム一治療介 入一．初版．青森：凸版メディア；2010,1-208.

50）一般社団法人日本顎関節学会初期治療ガイドライン作成 委員会. 䕱関節症患者のための初期治療診療ガイドライ ン2．開口障害を主訴とする顎関節症患者に対する自己 開口訓練について。一般歯科医師編。<http:// kokuhoken.net/jstmj/file/guideline/guideline_TMJ_ patient_2.pdf $>$ [accessed 20 Julu, 2012]. 
51）後藤基誉，永田和裕，菅原佳広。開口制限を伴う顎関節 症患者に対する Jog-manipulation technique の短期的 治療効果 RCT による評価. 日顎誌 2010;22: 84-91.

52）水口 一. 非復位性関節円板前方転移症例における各種 初期治療の有效性 Randomized Controlled Trial に よる解析. 岡山歯誌 1999; 18:49-67.

53) Crider AB, Glaros AG. A meta-analysis of EMG biofeedback treatment of temporomandibular disorders. J Orofac Pain 1999; 13:29-37.

54) Crider A. Glaros AG. Gevirtz RN. Efficacy of biofeedback-based treatments for temporomandibular disorders. Appl Psychophysiol Biofeedback 2005; 30:333-345.

55) Petrucci A, Sgolastra F, Gatto R, Mattei A, Monaco A. Effectiveness of low-level laser therapy in temporomandibular disorders: a systematic review and metaanalysis. J Orofac Pain 201 1; 25:298-307.

56) Cho SH. Whang WW. Acupuncture for temporomandibular disorders: a systematic review. J Orofac Pain 2010;24: 152-162.

57) La Touche R, Goddard G, De-la-Hoz JL, Wang K. Paris -Alemany A. Angulo-Diaz-Parreno S et al. Acupuncture in the treatment of pain in temporomandibular disorders: a systematic review and meta-analysis of randomized controlled trials. Clin J Pain 2010; 26: 541-550.

58) Ernst E, White AR. Acupuncture as a treatment for temporomandibular joint dysfunction: a systematic review of randomized trials. Arch Otolaryngol Head Neck Surg 1999; 125:269-272.

59) Jung A, Shin BC, Lee MS, Sim H. Ernst E. Acupuncture for treating temporomandibular joint disorders: a systematic review and meta-analysis of randomized, sham-controlled trials. J Dent 201 1; 39:341-350.

60) Watanabe M, Takeda S, Ikeuchi H. Atlas of Arthroscopy 2nd ed, Tokyo: Igaku Shoin; 1969: 12-15.

61）大西正俊。顎関節腔内穿刺法とその応用に関する臨床的 研究. 口病誌 1970; 37: 178-207.

62）大西正俊。顎関節の関節鏡的検査法. 口病誌 1975; 42 : 207-213.

63）大西正俊。顎関節鏡視法の開発とその臨床応用．口科誌 1982;31:487-512.

64）大西正俊．大月佳代子，中山英二．顎関節の手術用関節 鏡の開発. 関節鏡 1988; 13: 133-136.

65）大西正俊。顎関節-鏡視法ならびに鏡視下手術。池内 宏, 古屋光太郎, 松井宣夫. 関節鏡, 東京 : 南江堂 ; 1995, 317-328.

66) Reston JT. Turkelson CM. Meta-analysis of surgical treatments for temporomandibular articular disorders: a reply to the discussants. J Oral Maxillofac Surg 2003;61:737-738.
67) Bessa-Nogueira RV, Vasconcelos BC, Niederman R. The methodological quality of systematic reviews comparing temporomandibular joint disorder surgical and non-surgical treatment. BMC Oral Health 2008; 8: 27.

68) Nitzan DW, Dolwick MF, Heft MW. Arthroscopic lavage and lysis of the temporomandibular joint: a change in perspective. J Oral Maxillofac Surg 1990; 48:798-801.

69) Nitzan DW, Dolwick MF, Martinez GA. Temporomandibular joint arthrocentesis: a simplified treatment for severe, limited mouth opening. J Oral Maxillofac Surg 1991; 49: 1 163-1167.

70) Nitzan DW, Samson B, Better H. Long-term outcome of arthrocentesis for sudden-onset, persistent, severe closed lock of the temporomandibular joint. J Oral Maxillofac Surg 1997; 55: 151-157.

71) Nitzan DW. Arthrocentesis--incentives for using this minimally invasive approach for temporomandibular disorders. Oral Maxillofac Surg Clin North Am 2006; 18:311-328.

72) Guo C. Shi Z. Revington P. Arthrocentesis and lavage for treating temporomandibular joint disorders. Cochrane Database Syst Rev 2009; 4: CD 004973.

73) Fridrich KL, Wise JM, Zeitler DL. Prospective comparisonof arthroscopy and arthrocentesis for temporomandibularjoint disorders. J Oral Maxillofac Surg 1996; 54: 816-820.

74) Goudot P, Jaquinet AR, Hugonnet S, Haefliger W, RichterM. Improvement of pain and function after arthroscopyand arthrocentesis of the temporomandibular joint: acomparative study. J Craniomaxillofac Surg 2000; 28: 39-43.

75) Tozoglu S. AI-Belasy F A. Dolwick MF.A review of techniques of lysis and lavage of TMJ. Br J Oral Maxillofac Surg 201 1; 49:302-309.

76) Rigon M, Pereira LM, Bortoluzzi MC, Loguercio AD, Ramos AL, Cardoso JR. Arthroscopy for temporomandibular disorders. Cochrane Database Syst Rev 2011; 5: CD 006385.

77) Fricton JR, Ouyang W, Nixdorf DR, Schiffman EL, Velly AM. Look JO. Critical appraisal of methods used in randomized controlled trials of treatments for temporomandibular disorders. J Orofac Pain 2010;24: 139-151.

\footnotetext{
著者連絡先：柴田 考典

T061-0293 北海道石狩郡当別町金沢 1757

Tel/Fax: 0133-23-1429

E-mail: tshibata@hoku-iryo-u.ac.jp
} 


\title{
Therapeutic Modalities for Temporomandibular Joint Arthrosis in the Speciality of Oral and Maxillofacial Surgery
}

Takanori Shibata, DDS, PhD

\begin{abstract}
Division of Reconstructive Surgery for Oral and Maxillofacial Region, Department of Human Biology and Pathophysiology, School of Dentistry, Health Sciences University of Hokkaido
\end{abstract}

Ann Jpn Prosthodont Soc 4 : 246-255, 2012

\section{ABSTRACT}

Purpose: This manuscript inspects the therapeutic outcomes of pharmacological therapies, physical medicine modalities, and surgical modalities (found in published articles) that the oral surgery domain is mainly in charge of among various therapeutic modalities in temporomandibular arthrosis. It aims to determine the therapeutic modalities with conclusive evidence and also the necessary criteria for the selection of these obtained therapeutic modalities.

Method: On April 1, 2012, we electronically searched randomized controlled trials (RCTs), systematic reviews (SRs), the Cochrane Database of Systematic Reviews (Cochrane Reviews), and the meta-analysis (Meta-A) concerning pharmacological therapies, physical medicine modalities, and surgical modalities of temporomandibular arthrosis or TMD from the database of Medline and Ichushi. We next reevaluated the RCTs adopted by the selected articles about homogeneity and validity of research design.

Results: Information on pharmacological therapies, arthrocentesis, and arthroscopy was available in the Cochrane Reviews. A very large number of RCTs, SRs, and Meta-A about pharmacological therapies was available, and a lesser number offered data concerning surgical modalities.

Conclusions: The effectiveness of self-mouth opening exercises, internal use of NSAIDs, and acupuncture for temporomandibular arthrosis was revealed. In the future we expect to learn the effectiveness of the accumulation of homogeneous RCTs of temporomandibular arthrosis.

\section{Key words}

temporomandibular arthrosis, pharmacologic therapies, physical medicine modalities, surgical modalities, therapeutic outcome 